\title{
PENGARUH RELAKSASI NAFAS DALAM DENGAN TEKNIK MENIUP BALON TERHADAP PERUBAHAN SKALA NYERI PASCA OPERASI SEKSIO SESAREA DI RSIA BAHAGIA MAKASSAR
}

\author{
Ar. Megawahyuni' ${ }^{1}$, Hasnah'2, Mariah Ulfah Azhar ${ }^{3}$. \\ 1,2 Mahasiswa Fakultas Kedokteran dan Ilmu Kesehatan UIN Alauddin Makassar \\ ${ }^{3}$ Dosen Fakultas Kedokteran dan Ilmu Kesehatan UIN Alauddin Makassar \\ *70300114037@uin-alauddin.ac.id, **hasnahners@gmail.com, ***mariaulfah697@gmail.com
}

DOI : 10.24252/jkesehatan.v11i1.5028

\begin{abstract}
Abstrak
Persalinan seksio sesarea semakin banyak diminati oleh ibu hamil di negara maju, hal ini dikarenakan ilmu pengetahuan dan teknologi yang terus berkembang hingga saat ini. Secara fisiologis, tindakan operasi seksio sesarea dapat menimbulkan dampak pasca operasi yaitu nyeri. Penatalaksanaan nyeri pada pasca operasi seksio sesarea terdiri dari penatalaksanaan farmakologi dan non farmakologi. Salah satu teknik yang dapat digunakan untuk menurunkan skala nyeri secara non farmakologi yaitu dengan latihan relaksasi nafas dalam dengan teknik meniup balon. Tujuan penelitian yaitu mengetahui pengaruh relaksasi nafas dalam dengan teknik meniup balon terhadap perubahan skala nyeri pasca operasi seksio sesarea di RSIA Bahagia Makassar. Metode penelitian yang digunakan yaitu Quasi Eksperiment dengan pendekatan one group pre and post test design. Sampel pada penelitian ini berjumlah 30 responden ibu pasca operasi seksio sesarea dengan 24 jam pertama menggunakan teknik accidental sampling. Pengambilan data dilakukan di ruang perawatan nifas dengan menggunakan lembar observasi dan skala ukur nyeri NRS (Numeric rating Scale) pada tanggal 16 Januari 2018 sampai 16 Februari 2018. Analisa data yang digunakan yaitu Uji Wilcoxon. Hasil Penelitian menunjukkan bahwa skala nyeri sebelum dilakukan intervensi adalah 7.03 dimana nilai tersebut masuk dalam kategori nyeri berat. Sedangkan skala nyeri setelah diberikan intervensi relaksasi nafas dalam dengan teknik meniup balon adalah 2.20 dimana nilai tersebut masuk dalam kategori nyeri ringan. Hasil analisis yang telah diperoleh dengan menggunakan uji wilcoxon yaitu $\mathrm{p}=0,000(\mathrm{p}<0,05)$. Hal ini membuktikan bahwa Ha diterima yaitu ada pengaruh relaksasi nafas dalam dengan teknik meniup balon terhadap perubahan skala nyeri pasca operasi seksio sesarea. Jadi dapat disimpulkan bahwa terdapat perbedaan yang signifikan antara skala nyeri sebelum dan setelah diberikan relaksasi nafas dalam dengan teknik meniup balon.
\end{abstract}

\section{Kata Kunci: Seksio Sesarea, Nyeri, Relaksasi Nafas Dalam, Meniup Balon}

\section{Abstract}

Delivery of cesarean section is increasingly in demand by pregnant women in developing country, this is because science and technology continue to develop today. Physiologically, the action of cesarean section surgery can cause postoperative effects of pain. Pain management in postoperative cesarean 
section consists of pharmacological and non-pharmacological management. One technique that can be used to reduce pain scale non-pharmacologically is by deep breathing relaxation exercises with balloon blowing techniques. Objective in this research is to determine the effect of deep breathing relaxation with balloon blowing techniques on changes in postoperative cesarean section pain scale in hospital clinical of Bahagia Makassar. The design of this study is Quasi Experiment with one group approach pre and posttest design. The sample in this study amounted to 30 maternal respondent postoperative cesarean section with the first 24 hours using accidental sampling technique. Data collection was carried out in the postpartum care room by using observation sheets and NRS (Numeric rating scale) pain measuring scales on January 16, 2018 to February 16, 2018. The data analysis used was the Wilcoxon Test. The results of this study indicate that the pain scale before intervention is 7.03 where the value falls into the category of severe pain. While the pain scale after being given intervention relaxes the deep breath with the technique of blowing balloon 2.20 where the value falls into the category of mild pain. The results of the analysis that have been obtained using the Wilcoxon test are $p=0,000(p<0.05)$. This proves that Ha is accepted that there is an effect of deep breath relaxation with balloon blowing techniques on changes in postoperative pain scale of cesarean section. So it can be concluded that there are significant differences between pain scales before and after being given deep breathing relaxation with balloon blowing techniques.

\section{Keywords: Caesarean section, Pain, Deep Breath Relaxation, Balloon Blowing}

\section{PENDAHULUAN}

Seksio Sesarea adalah salah satu operasi yang saat ini banyak menjadi pilihan bagi ibu hamil di negara maju yang disebabkan karena kemajuan ilmu pengetahuan dan teknologi yang terus berkembang pada saat ini, terutama dalam bidang kesehatan. Angka kejadian (insidensi) seksio sesarea mengalami peningkatan hampir di seluruh dunia (Wahyuni, 2010). Menurut Word Health Organization (WHO), sejak tahun 1985 komunitas kesehatan internasional telah mempertimbangkan tingkat ideal untuk operasi sesarea menjadi antara $10 \%$ dan $15 \%$. Sejak saat itu, operasi sesarea telah menjadi semakin umum pada negara maju dan berkembang (World Health Organization, 2015).

Pada dasarnya, persalinan yang dilakukan dengan pervaginam lebih aman dilakukan jika dibandingkan dengan tindakan seksio sesarea. Efek samping dari obatobatan yang diberikan saat operasi seksio sesarea dilakukan lebih berbahaya dari pada pervaginam. Masa penyembuhan luka akibat proses persalinan juga akan lebih lama jika dibandingkan persalinan pervaginam, serta pada persalinan seksio sesarea dapat menimbulkan masalah yang kompleks bagi ibu hamil baik secara fisik, psikologis, sosial, dan spiritual (Hartati, 2014).

Dampak fisik atau fisiologis yang sering muncul pada pasien pasca seksio sesarea adalah nyeri sebagai akibat adanya torehan jaringan yang menyebabkan kontinuitas jaringan terputus. Rasa nyeri yang dirasakan biasanya membuat pasien merasa tidak nyaman karena pasien merasa sangat kesakitan. Ketidaknyamanan atau nyeri tersebut 
harus diatasi sesuai dengan manajemen nyeri, karena ketidaknyamanan merupakan kebutuhan dasar manusia yang harus dipenuhi (Hutahaean, 2009).

Berdasarkan hasil wawancara yang telah dilakukan oleh peneliti dengan kepala ruangan di Ruang Nifas bahwa keluhan utama yang dirasakan oleh pasien pasca operasi seksio sesarea adalah nyeri. Adapun intervensi yang dilakukan oleh perawat untuk menghilangkan atau mengurangi nyeri pada pasien sebagian besar adalah berkolaborasi dengan dokter dalam pemberian obat analgetik. Pelaksanaan manajemen nyeri non farmakologi belum sepenuhnya dilakukan oleh perawat dalam mengatasi nyeri. Teknik relaksasi yang menjadi intervensi independent perawat masih sangat minim dilaksanakan. Penanganan nyeri akan lebih mudah jika terapi farmakologi dengan memperhatikan efek samping dapat dikombinasikan dengan terapi non farmakologi, seperti teknik relaksasi nafas dalam.

Relaksasi telah menjadi sebuah anjuran yang semakin populer untuk terapi analgesik konvensional. Relaksasi sudah digunakan secara luas dalam manajemen nyeri pasca bedah dan telah direkomendasikan dalam pengelolaan nyeri. Penelitian yang dilakukan oleh Seers dan Carroll (2005) untuk menyelidiki keefektifan teknik relaksasi saat digunakan sendiri dalam penanganan nyeri akut. Tiga dari tujuh penelitian yang mereka tunjukkan menunjukkan nyeri secara signifikan lebih sedikit atau rasa sakit tertekan relaksasi (Pyati dan Gan, 2007).

Teknik relaksasi nafas dalam merupakan salah satu metode non farmkologis yang telah direkomendasikan sebagai manajemen nyeri. Teknik relaksasi nafas dalam dapat dilakukan dengan berbagai metode seperti meniup balon. Teknik relaksasi nafas dalam dengan meniup balon efektif menurunkan intensitas nyeri pada anak post operasi megacolon, sehingga teknik relaksasi nafas dalam dengan meniup balon juga akan efektif dilakukan pada pasien pasca seksio sesarea. Oleh karena itu peneliti tertarik untuk melakukan penelitian yang berjudul "Pengaruh Relaksasi Nafas Dalam dengan Teknik Meniup Balon Terhadap Perubahan Skala Nyeri Pasca Operasi Seksio Sesarea di RSIA Bahagia Makassar".

\section{METODOLOGI PENELITIAN}

Metode penelitian yang akan dilakukan pada penelitian ini adalah metode deskriptif kuantitatif dengan desain penelitian quasi eksperiment dengan pendekatan one group pre and post test design. Penelitian dengan one group pre and post test design merupakan penelitian yang menggunakan satu kelompok subyek, pengukuran dilakukan sebelum diberikan intervensi dan setelah diberikan intervensi. Hasil pengukuran tersebut kemudian dilihat kembali perbedaan hasil pengukuran (Suyanto, 2011).

Penelitian ini dilakukan di RSIA Bahagia Makassar pada tanggal 16 Januari 2018 sampai 16 Februari 2018. Populasi dalam penelitian ini adalah seluruh pasien pasca 
operasi seksio sesarea di Rumah Sakit Ibu dan Anak Bahagia. Metode pengambilan sampel pada penelitian ini yaitu non probability dengan pendekatan Accidental Sampling dengan berdasarkan pada pasien pasca seksio sesarea yang ada pada saat penelitian. Jadi sampel dalam penelitian ini adalah seluruh pasien pasca operasi seksio sesarea sebanyak 30 responden dengan kriteria inklusi yaitu pasien pasca operasi seksio sesarea pada hari kedua, pasien dalam keadaan sadar penuh, pasien berusia kurang dari 40 tahun, dan pasien bersedia menjadi responden secara tertulis. Sedangkan kriteria ekslusinya yaitu pasien tidak kooperatif, pasien mengalami komplikasi setelah operasi seksio sesarea dan pasien mengalami gangguan pernafasan.

Instrumen penelitian yang digunakan dalam penelitian ini adalah dengan menggunakan balon serta lembar observasi yang berisi tentang pengkajian nyeri pasien sebelum dan setelah intervensi. Instrumen pengukuran skala nyeri menggunakan Numeric Rating Scale (NRS). Intervensi relaksasi nafas dalam diberikan selama 5 menit menggunakan balon dengan frekuensi 1 kali sehari selama 2 hari pada jam yang sama. Pemberian intervensi dimulai pada hari kedua pasca operasi seksio sesarea. Pengkajian nyeri dilakukan 5 menit sebelum dan setelah diberikan intervensi dengan menggunakan NRS.

Pengolahan data menggunakan software statistik (SPSS) dengan menggunakan dua cara dalam menganalisis data, yaitu anaisis data Univariat dan Bivariat. Uji hipotesis yang digunakan dalam penelitian ini yaitu menggunakan uji Wilcoxon.

\section{HASIL PENELITIAN}

1. Karakteristik Responden

a. Karakteristik Responden Berdasarkan Usia

\begin{tabular}{ccc}
\hline \multirow{2}{*}{ Usia } & \multicolumn{2}{c}{ Total } \\
& Jumlah & Presentase \\
\hline 17-25 & 6 & 20 \\
Tahun & 17 & 57 \\
26-35 Tahun & 7 & 23 \\
36-40 Tahun & 7 & $\mathbf{1 0 0}$ \\
\hline Jumlah & $\mathbf{3 0}$ &
\end{tabular}

b. Karakteristik Responden Berdasarkan Pendidikan

\begin{tabular}{ccc}
\hline \multirow{2}{*}{ Pendidikan } & \multicolumn{2}{c}{ Total } \\
& Jumlah & Presentase \\
\hline SMP & 2 & 7 \\
SMA & 12 & 40 \\
D3 atau S1 & 16 & 53 \\
\hline Jumlah & 30 & 100 \\
\hline
\end{tabular}


c. Karakteristik Responden Berdasarkan Pekerjaan

\begin{tabular}{ccc}
\hline Pekerjaan & Jumlah & $\begin{array}{c}\text { Total } \\
\text { Presentase }\end{array}$ \\
\hline IRT & 19 & 63 \\
PNS & 5 & 17 \\
Wiraswasta & 6 & 20 \\
\hline Jumlah & 30 & 100 \\
\hline
\end{tabular}

d. Karakteristik Responden Berdasarkan Paritas

\begin{tabular}{ccc}
\hline \multirow{2}{*}{ Paritas } & \multicolumn{2}{c}{ Total } \\
& Jumlah & Presentase \\
\hline Primipara & 10 & 33 \\
Multipara & 20 & 67 \\
\hline Jumlah & 30 & 100 \\
\hline
\end{tabular}

e. Karakteristik Responden Berdasarkan Riwayat SC

\begin{tabular}{ccc}
\hline \multirow{2}{*}{ Riwayat } & \multicolumn{2}{c}{ Total } \\
& Jumlah & Presentase \\
\hline Pertama & 22 & 73 \\
Berulang & 8 & 27 \\
\hline Jumlah & 30 & 100 \\
\hline
\end{tabular}

2. Analisis Univariat

a. Distribusi Skala Nyeri Sebelum dan Setelah Intervensi Hari Pertama

\begin{tabular}{ccc}
\hline \multirow{2}{*}{ Skala Nyeri } & \multicolumn{2}{c}{ Total } \\
& Jumlah & Presentase \\
\hline Nyeri Ringan & 1 & 3 \\
Nyeri Sedang & 11 & 37 \\
Nyeri Berat & 18 & 60 \\
\hline Jumlah & $\mathbf{3 0}$ & $\mathbf{1 0 0}$ \\
\hline
\end{tabular}

(Skala Nyeri Sebelum Intervensi)

\begin{tabular}{ccc}
\hline \multirow{2}{*}{ Skala Nyeri } & \multicolumn{2}{c}{ Total } \\
& Jumlah & Presentase \\
\hline Nyeri Ringan & 10 & 33 \\
Nyeri Sedang & 16 & 53 \\
Nyeri Berat & 4 & 14 \\
\hline Jumlah & $\mathbf{3 0}$ & $\mathbf{1 0 0}$ \\
\hline
\end{tabular}

(Skala Nyeri Sebelum Intervensi) 
b. Distribusi Skala Nyeri Sebelum dan Setelah Intervensi Hari Kedua

\begin{tabular}{ccc}
\hline \multirow{2}{*}{ Skala Nyeri } & \multicolumn{2}{c}{ Total } \\
& Jumlah & Presentase \\
\hline Nyeri Ringan & 4 & 13 \\
Nyeri Sedang & 26 & 87 \\
Nyeri Berat & - & - \\
\hline Jumlah & $\mathbf{3 0}$ & $\mathbf{1 0 0}$ \\
\hline
\end{tabular}

(Skala Nyeri Sebelum Intervensi)

\begin{tabular}{ccc}
\hline \multirow{2}{*}{ Skala Nyeri } & \multicolumn{2}{c}{ Total } \\
& Jumlah & Presentase \\
\hline Nyeri Ringan & 26 & 87 \\
Nyeri Sedang & 4 & 13 \\
Nyeri Berat & - & - \\
\hline Jumlah & $\mathbf{3 0}$ & $\mathbf{1 0 0}$ \\
\hline
\end{tabular}

(Skala Nyeri Sebelum Intervensi)

3. Analisis Bivariat

a. Uji Normalitas

\begin{tabular}{lccc}
\hline \multicolumn{1}{c}{ Variabel } & \multicolumn{3}{c}{ Shapiro-Wilk } \\
& Statistic & Df & Sig. \\
\hline Nyeri Pre H.1 & .686 & 30 & .000 \\
Nyeri Post H.1 & .789 & 30 & .000 \\
Nyeri Pre H.2 & .404 & 30 & .000 \\
Nyeri Post H.2 & .404 & 30 & .000 \\
\hline
\end{tabular}

b. Uji Wilcoxon

\begin{tabular}{lcc}
\hline \multicolumn{1}{c}{ Variable } & Z-test & $\begin{array}{c}\boldsymbol{p} \\
\text { value }\end{array}$ \\
\hline $\begin{array}{l}\text { Nyeri Pre (H.1) } \\
\text { Nyeri Post (H.2) }\end{array}$ & -4.849 & 0,000 \\
\hline
\end{tabular}

\section{PEMBAHASAN}

1. Karakteristik responden

Dari 30 responden frekuensi kelompok usia responden sebagian besar berusia antara 26 sampai 35 tahun yaitu berjumlah 17 responden (57\%). Sedangkan kelompok usia sebagian kecil yaitu berusia 17 - 25 tahun sebanyak 6 responden (20\%). Adapun kelompok usia 36 - 40 tahun yaitu sebanyak 7 responden (23\%). 
Menurut Depkes (2009), usia 26 - 35 tahun adalah masa dewasa awal yang merupakan usia yang dianggap ideal untuk menjalani kehamilan dan persalinan karena pada usia 26 - 35 tahun seorang ibu sudah memiliki kesiapan mental yang baik sehingga memiliki potensi resiko yang rendah. Berbeda dengan usia remaja akhir dan dewasa akhir, pada usia tersebut memiliki resiko yang tinggi terhadap keselamatan selama proses persalinan.

Frekuensi tingkat pendidikan responden sebagian besar adalah D3 atau S1 yaitu sebanyak 16 responden (53\%). Sedangkan frekuensi tingkat pendidikan yang terkecil yaitu SMP sebanyak 2 responden (7\%). Semakin tinggi tingkat pendidikan seorang ibu maka semakin tinggi pula perhatian terhadap kesehatannya sehingga persalinan operasi seksio sesarea lebih berpeluang terjadi pada ibu dengan tingkat pendidikan yang lebih tinggi (Sihombing, 2017)

Seorang ibu yang bekerja akan memiliki kecenderugan untuk mengambil sebuah keputusan atau pertimbangan. Status pekerjaan yang paling banyak adalah IRT yaitu sebanyak 19 responden (63\%), sedangkan PNS merupakan status pekerjaan yang paling sedikit yaitu sebanyak 5 responden $(17 \%)$.

Frekuensi tingkat paritas responden adalah multipara yaitu sebanyak 20 responden (67\%), sedangkan tingkat paritas primipara sebanyak 10 responden (33\%). Adapun frekuensi riwayat seksio searea sebagian besar adalah pertama kali melakukan operasi seksio sesarea yaitu sebanyak 22 responden $(73 \%)$, sedangkan yang berulang sebanyak 8 responden $(27 \%)$.

\section{Univariat}

Berdasarkan tabel di atas menunjukkan bahwa skala nyeri yang dirasakan oleh responden sebelum diberikan intervensi pada hari pertama sebagian besar berada pada kategori nyeri berat yaitu sebanyak 18 responden $(60 \%)$, sedangkan untuk yang nyeri ringan hanya terdapat 1 responden (3\%). Sedangkan setelah diberikan intervensi sebagian besar berada pada kategori nyeri sedang sebanyak 16 responden (53\%) dan yang berada pada kategori nyeri berat menjadi 4 responden (14\%).

Pada hari kedua, skala nyeri yang dirasakan oleh responden sebelum diberikan intervensi sebagian besar berada pada kategori nyeri sedang yaitu sebanyak 26 responden $(87 \%)$, sedangkan setelah diberikan intervensi skala nyeri terbanyak yang dirasakan oleh responden yaitu berada pada kategori nyeri ringan yaitu sebanyak 26 responden (87\%). Sedangkan untuk kategori sedang sebanyak 4 responden (13\%) dan tidak ada lagi responden yang merasakan skala nyeri berat setelah diberikan intervensi pada hari kedua. 


\section{Bivariat}

Pada uji normalitas dengan menggunakan uji Shapiro-Wilk, diperoleh nilai p sebelum diberikan intervensi dan setelah diberikan intervensi pada hari pertama yaitu $p=0.000$, begitu halnya pada hari kedua yang juga diperoleh nilai $p=0.000$. Hal ini menunjukkan bahwa nilai $\mathrm{p}<0,005$, sehingga dapat disimpulkan bahwa data berdistribusi tidak normal, sehingga uji yang dilakukan untuk melihat pengaruh sebelum dan setelah diberikan intervensi relaksasi nafas dalam dengan teknik meniup balon yaitu dengan menggunakan uji Wilcoxon.

Hasil uji statistik yang telah dilakukan dengan menggunakan uji Wilcoxon diperoleh nilai $\mathrm{p}$ value sebesar 0.000. Secara statistik, jika nilai $\mathrm{p}<0,05$ maka Ha diterima. Oleh karena itu, berdasarkan hasil analisis tersebut dapat diambil kesimpulan bahwa terdapat pengaruh relaksasi nafas dalam dengan meniup balon terhadap perubahan skala nyeri pasca operasi seksio sesarea di RSIA Bahagia Makassar.

Relaksasi nafas dalam adalah salah satu terapi non farmakologis yang dapat dilakukan untuk merilekskan ketegangan otot sehingga dapat mempengaruhi skala nyeri pada ibu pasca operasi seksio sesarea. Relaksasi nafas dalam dapat dilakukan secara mandiri karena tidak memiliki efek samping, mudah dalam pelaksanaannya serta tidak memerlukan biaya dan waktu yang cukup banyak. Ketika melakukan teknik relaksasi nafas dalam, ibu pasca operasi seksio sesarea hanya perlu memposisikan badannya dengan senyaman mungkin, kemudian melakukan relaksasi nafas dalam dengan frekuensi nafas yang lambat dan berirama.

Dalam melakukan relaksasi nafas dalam, ada beberapa teknik modifikasi yang dapat dilakukan untuk menghilangkan ketegangan otot sehingga dapat mempengaruhi persepsi seseorang terhadap nyeri. Salah satunya yaitu penelitian yang telah dilakukan oleh Wahyuni (2015) dengan memodifikasi relaksasi nafas dalam dengan menggunakan teknik meniup baling-baling kertas. Hasil penelitian tersebut menunjukkan bahwa relaksasi nafas dalam dengan teknik meniup baling-baling kertas efektif menurunkan skala nyeri pada anak yang akan dilakukan penyuntikan anastesi sirkumsisi. Selain itu, penelitian lain yang dilakukan oleh Handayani, dkk (2017), bahwa relaksasi nafas dalam dengan menggunakan aroma terapi efektif terhadap penurunan nyeri akut dan kronis.

Nyeri pasca operasi seksio sesarea akan timbul setelah hilangnya efek dari pembiusan, nyeri hebat yang dirasakan 24 jam pertama atau hari ke dua pasca operasi baik pasien yang pertama kali dilakukan seksio sesarea sebelumnya maupun yang sudah berulang (Sulaminingsih, 2012). Di dalam Al-Qur'an tampaknya tidak ada ayat yang menyatakan rasa nyeri secara spesifik, namun dijelaskan bahwa rasa sakit yang dirasakan oleh seorang ibu ketika akan melahirkan anaknya merupakan rasa nyeri yang luar biasa, seperti firman Allah SWT: 


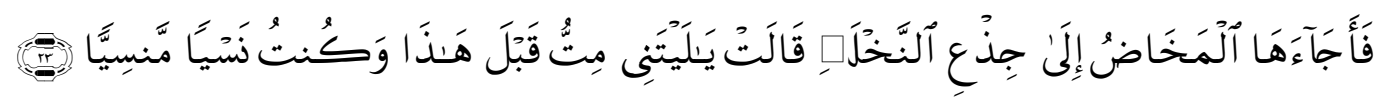

Terjemahnya:

"Maka rasa sakit akan melahirkan anak memaksa ia (bersandar) pada pangkal pohon kurma, dia berkata: "Aduhai, alangkah baiknya Aku mati sebelum ini, dan Aku menjadi barang yang tidak berarti, lagi dilupakan"." (QS. Maryam/19: 23).

Ayat ini menjelaskan bahwa ketika Maryam hendak melahirkan seorang anak, beliau merasakan nyeri yang sangat berat, sehingga beliau bersandar disebuah pangkal pohon kurma. Hal ini membuktikan bahwa rasa sakit atau nyeri yang dirasakan seorang ibu ketika hendak melahirkan anaknya terutama pasca operasi seksio sesarea menandakan bahwa betapa besar perjuangan seorang ibu untuk melahirkan anaknya ke dunia. Oleh karena itu, jelas perintah Allah SWT. untuk selalu berbakti kepada orang tua terutama kepada ibu.

Relaksasi nafas dalam menciptakan sensasi melepaskan ketidaknyamanan dan stress. Secara bertahap, klien dapat merileksasi otot tanpa harus terlebih dahulu menegangkan otot-otot tersebut. Ketika individu telah mencapai tingkat relaksasi penuh, maka persepsi nyeri akan berkurang dan perasaan cemas terhadap pengalaman nyeri menjadi berkurang (Hapsari, 2013).

Sebagai seorang perawat yang telah memiliki ilmu keperawatan mempunyai posisi penting dalam membantu memenuhi kebutuhan rasa nyaman akibat nyeri dan rasa aman cemas yang dirasakan oleh ibu pasca operasi seksio sesarea dengan mengurangi rasa nyeri tersebut. Sesungguhnya usaha seorang perawat dalam membantu ibu pasca operasi seksio sesarea untuk mengurangi rasa nyerinya tak luput dari kehendak Allah swt., sebagaimana firman Allah swt. :

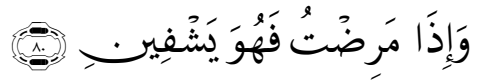

Terjemahnya:

"Dan apabila Aku sakit, dialah yang menyembuhkan aku" (QS. Asy-Syu'araa/26:80).

Ayat tersebut telah dijelaskan bahwa kita sebagai hamba-Nya hanya mampu berusaha untuk mengurangi rasa nyeri yang dirasakan dan intervensi yang telah diberikan yaitu relaksasi nafas dalam dengan teknik meniup balon untuk mengurangi skala nyeri yang dirasakan oleh ibu pasca operasi sesarea hanyalah sebagai perantara dan hanya Allah swt. lah yang mampu menyembuhkan segalanya.

\section{KESIMPULAN}

Relaksasi nafas dalam dengan teknik meniup balon memiliki pengaruh terhadap perubahan skala nyeri pasca operasi seksio sesarea di RSIA Bahagia Makassar. Berdasarkan uji wilcoxon diperoleh nilai $p$ value adalah $0,000(p<0,05)$. Sehingga terapi relaksasi nafas dalam dengan teknik meniup balon dapat menjadi salah satu intervensi 
yang digunakan untuk mengurangi skala nyeri yang dirasakan, karena terapi ini tidak memerlukan biaya dan waktu yang banyak. Untuk penelitian selanjutnya yang ingin meneliti lebih jauh tentang pengaruh relaksasi nafas dalam dengan teknik meniup balon terhadap perubahan skala nyeri dapat menjadikan penelitian ini sebagai dasar dengan menggunakan sampel yang lebih besar lagi serta mengkombinakasikan skala ukur yang digunakan yaitu skala ukur NRS (Numeric rating Scale) dangan skala ukur yang lain.

\section{DAFTAR PUSTAKA}

Al-Qur'an dan Terjemahnya. Kementerian Agama RI.

Handayani, N. Dkk. (2017). Penerapan Teknik Nafas Dalam dan Aroma Terapi Bunga Mawar Terhadap Penurunan Nyeri Dismenore Pada Remaja Putri.

Hapsari, R, W dan Tri Anasari. (2013). Efektivitas Teknik Relaksasi Nafas Dalam dan Metode Pemberian Cokelat Terhadap Penurunan Intensitas Dismenore Pada Remaja Putri Di Smk Swagaya 2 Purwokerto. "Jurnal Involusi Kebidanan". 3 (5). Diakses 18 Januari 2018.

Hartati, S dan Maryunani, A. (2014). Asuhan Keperawatan Ibu Post Partum Seksio Sesarea (Pendekatan Teori Model Selfcare dan Comfart), Jakarta Timur: CV. Transa Info Media.

Hutahaean, S. (2009). Asuhan Keperawatan Dalam Maternitas \& Ginekologi. Jakarta: Katalog Dalam Terbitan (KDT).

Pyati, S., \& Gan, T. J. (2007). Perioperative pain management. CNS Drugs, 21(3), 185211. https://doi.org/10.2165/00023210-200721030-00002

Sulaminingsih, et al. (2012). Perbedaan Nyeri Pada Pasien Pasca Operasi Sectio Caesar Pertama dengan Pasien Pasca Operasi Sectio Caesar Berulang yang Diberikan Ketolorac 30 Mg di RSUD Ambarawa.

Sugiyono. (2010). Metode Penelitian Pendidikan Pendekatan Kuantitatif, Kualitatif, dan $R \mathcal{E D}$. Bandung: Alfabeta.

Wahyuni, H. Dkk. (2015). Terapi Slow Deep Breathing Dengan Bermain Meniup BalingBaling Terhadap Intensitas Nyeri Pada Anak Yang Dilakukan Penyuntikan Anestesi Sirkumsisi. “Jurnal Skolastik Keperawatan". 1(2).

Wahyuni, S. Dkk. (2010). Model Konsep \& Teori Keperawatan Aplikasi pada Kasus Obstetri Ginekologi. Bandung: PT. Refika Aditama.

World Health Organization. (2015). WHO Statement on Caesarean Section Rates. Retrieved from www.who.int/reproductivehealth/ 